\title{
Water Retention Problem in the Mountain Areas: a Case of Sola River Flows, Polish Carpathians
}

\author{
Andrzej Jaguś ${ }^{1}$ \\ 1 University of Bielsko-Biala, Willowa 2, 43-309 Bielsko-Biała, Poland \\ e-mail: ajagus@ath.bielsko.pl
}

\begin{abstract}
The paper considers mountain rivers, which usually feature high dynamics of hydrological phenomena. The variability of the Sola river flows in the Polish Carpathians is presented based on water-gauge measurements from the hydrological long-period of 1956-2015. The flows for the upper section of the river, where no storage reservoirs are found, were analysed. A broad range of flows was shown - from 0.59 to $1250 \mathrm{~m}^{3} / \mathrm{s}$ at a mean flow of $15.5 \mathrm{~m}^{3} / \mathrm{s}$. It was also shown that within a year, the flows grow in the spring (thaw freshets) and summer periods (rainwater freshets). Mainly the summer freshets are dangerous, consisting in a sudden rise of the flow due to rains. This is shown by the high values of maximum flows in June and July. In the case of mountain rivers, such as the Sola river, it is necessary to undertake the actions stabilising the flows, which on the one hand have flood-prevention importance, and on the other hand protect the water resources in long dry periods. The actions should be concentrated on the proper arrangement of the catchment area, slowing down the rainwater outflow. Appropriate land use is especially important (distribution of forests, of arable and developed areas) depending on the land elevation above the sea level and inclination, as well as creation of small storage facilities.
\end{abstract}

Keywords: mountain river, river flows, river regime, surface runoff, water retention

\section{INTRODUCTION}

The water resources of rivers are analysed based on the information about the water flows (Mathison et al. 2015, Wurbs and Kim 2011). In Poland, it is especially important to know the so-called characteristic flows (annual and longterm), which enables, i.a. forecasting flood phenomena, defining disposable water resources, or determining instream flows (Byczkowski 1999). The data about flows, in particular when they comprise a period of many years, also provide an analytical material to recognise the so-called river regime, i.e. a rhythmical course of hydrological phenomena in the river during a year (Walega and Mlynski 2017, Wrzesinski and Sobkowiak 2018).

The knowledge of characteristic flows and of the regime is important especially in the case of mountain rivers. It is widely known that a large part of water resources originates in the mountains and that only the mountains supply the lowland areas with water, which are poorer in that respect. The flows in mountain rivers are usually highly variable, which results from a high share of surface runoff in the total outflow (Baran-Gurgul et al. 2018, Stoffel et al. 2016). A fast runoff of water after rainfalls on the one hand creates a flood hazard and can result in water shortages in longer dry periods on the other. If such problems exist, then the actions stabilising the flows are necessary, including construction of storage reservoirs or creation of favourable conditions for water infiltration into the ground (Ryffel et al. 2014).

The paper presents the analysis of the Sola river flows, in the Polish Carpathians, in the Beskids mountain range. This is a region of high relief, where the intensification of the surface runoff is favoured on the natural side - apart from the land slope - by a poor water-bearing capacity of the bedrock (flysh geological structure) and by irregular precipitation supply (Dynowska 1991). Moreover, the anthropogenic pressure, 
manifesting itself among other things in the forest ecosystems degradation, an excessive number of farm roads, and a large acreage of paved areas, can also be observed (Wyzga et al. 2018).

The determination of characteristic flows and the recognition of the Sola river regime features based on the data from the water-gauge profile in the city of Zywiec, closing the upper section of its course, was the first objective of the paper. The second goal consisted in the discussion of the water resources protection in the Polish Carpathians taking into account problems observed in the drainage basin of the upper Sola river.

\section{UPPER SOLA RIVER}

The Sola river is a right-bank tributary of the Vistula river, $89.17 \mathrm{~km}$ long and with the basin of $1360.97 \mathrm{~km}^{2}$ area. It is one of main Carpathian rivers of the southern Poland. Its course may be divided into 3 sections (Figure 1). In the first (upper) section, $40 \mathrm{~km}$ long - from the source to the city of Zywiec - Sola is a typical mountain river with a gradient of $9.8 \%$. The second (central) section consists in the river flow through the Sola River Cascade, i.e. dam reservoirs: Tresna, Porabka, and Czaniec, occupying the $19.8 \mathrm{~km}$ long valley downstream the city of Zywiec. In the third (lower) section, $29.4 \mathrm{~km}$ long - below the cascade - the Sola flows through piedmont areas to the Vistula river in the city of Oswiecim.

The first section was chosen for the flow analysis, closed by the water-gauge profile named 'ZYWIEC', situated upstream the river inflow to the Tresna reservoir (Figure 2). The river regime in this section is characteristic of the rivers in the Polish Carpathians, because the flows are not subject to the intended man-made regulations. In the reservoirs of the Sola River Cascade, water management is the only factor that changes the river hydrological parameters entirely (Jagus 2018).

Solanka is a source stream of Sola. From the junction with the Czerna stream (in Sol village) Solanka takes the name of Sola. The upper Sola river flows through the following villages: Sol, Rycerka Dolna, Rajcza, Milowka, Cisiec, Wegierska Gorka, Ciecina, Wieprz, and the city of Zywiec. The more important tributaries of the upper Sola include: Rycerka, Woda Ujsolska (Ujsola), Nickulina, Salamonka, Bystra (Kamesznica), Zabniczanka, Ciecinka, Juszczynka, Wisnik (Radziechowka), Lesnianka, and
Koszarawa (Figure 2). In terms of administration, there are 9 municipalities in the drainage basin area: Ujsoly, Rajcza, Milowka, Wegierska Gorka, Radziechowy-Wieprz, Koszarawa, Jelesnia, Swinna, and Zywiec (Figure 2).

The upper Sola catchment area is bag-shaped and features a high relief. Its boundary passes through popular mountaintops of the Polish Carpathians - Barania Gora (1220 m a.s.1.), Wielka Racza (1236 m a.s.1.), and Pilsko (1557 m a.s.1.). Pilsko is the highest point in the upper Sola drainage basin, while the lowest point is the studied 'ZYWIEC' water-gauge profile, situated at an altitude of $344 \mathrm{~m}$ a.s.l. The entire area has a high relief (mountains).

The Sola river outflow breakdown was analysed by Kusmierski (1991). In the balance equation for the water-gauge profile in Rajcza in the long-period of 1965-1988 he obtained the following values:

$$
\begin{gathered}
1262(\mathrm{P})-445\left(\mathrm{Q}_{\mathrm{s}}\right)-37\left(\mathrm{Q}_{\mathrm{ss}}\right)-161\left(\mathrm{Q}_{\mathrm{g}}\right)- \\
-619(\mathrm{E})=0
\end{gathered}
$$

where: $P$-average precipitation $[\mathrm{mm}]$;

$Q_{s}$ - average surface runoff $[\mathrm{mm}]$;

$Q_{s s}$ - average subsurface runoff [mm];

$Q_{g}$ - average underground runoff [mm];

$E$ - average evaporation [mm].

The equation shows that the surface runoff constituted as much as $69 \%$ of the total outflow. As a result of such outflow breakdown, Sola is characterised by inclination to sudden rises, which is observed by the residents of this river valley. The observation shows the summer freshets, occurring as a result of torrential or long-lasting rains are the problem, rather than the spring thaw freshets (from the snow cover melting).

\section{METHODS}

The analysis of the Sola river flows was carried out for a hydrological 60-year period of 1956-2015 (from 1st November 1955 to 31st October 2015). Consideration of such a long period was possible due to the operation of the watergauge in Zywiec. The water-gauge is situated downstream the main city bridge and is owned by the Institute of Meteorology and Water Management (IMGW), and its identifier is: 149190100 'ZYWIEC'. This water-gauge closes the drainage basin of $782.81 \mathrm{~km}^{2}$ area (Figure 2). 


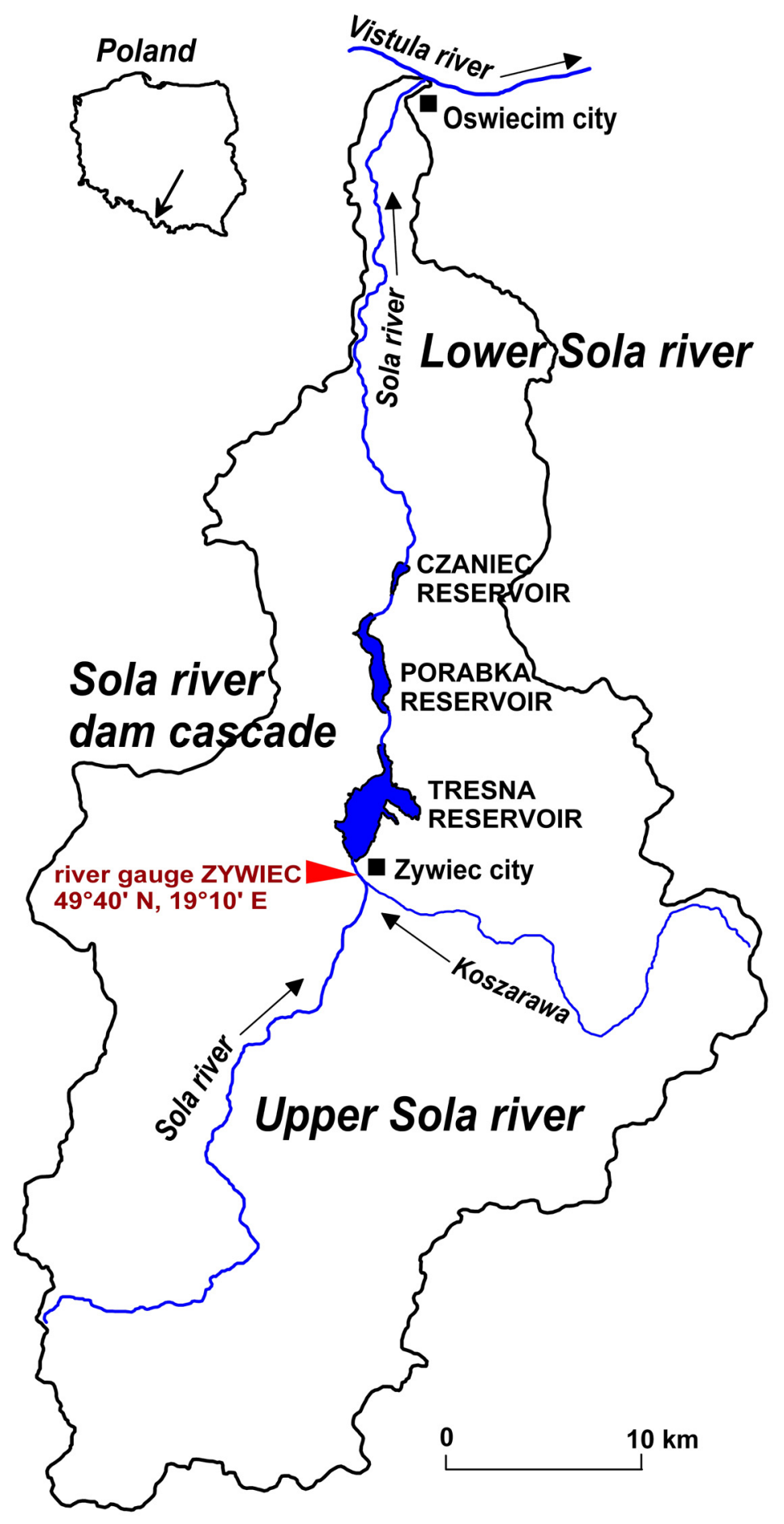

Figure 1. Sola river drainage basin with the researched water-gauge location

The water-gauge profile is a permanent step across the river bed, above which water flows (Figure 3). The profile is stable, which results in high accuracy of measurements. The top edge of the profile is situated on the datum of $344 \mathrm{~m}$ a.s.l. Its height slightly exceeds $1 \mathrm{~m}$.

The flow values for the entire period (60 years) were acquired from the IMGW public hydrological database. The daily (everyday) values were collected. Thus, the analysis comprised almost 22,000 results. This paper presents the characteristic flows - annual and long-term given in $\mathrm{m}^{3} / \mathrm{s}$. The annual flows, determined from 365 or 366 days, are as follows:

- NQ - minimum within a year;

- $\mathrm{SQ}$ - mean annual;

- WQ - maximum within a year. 


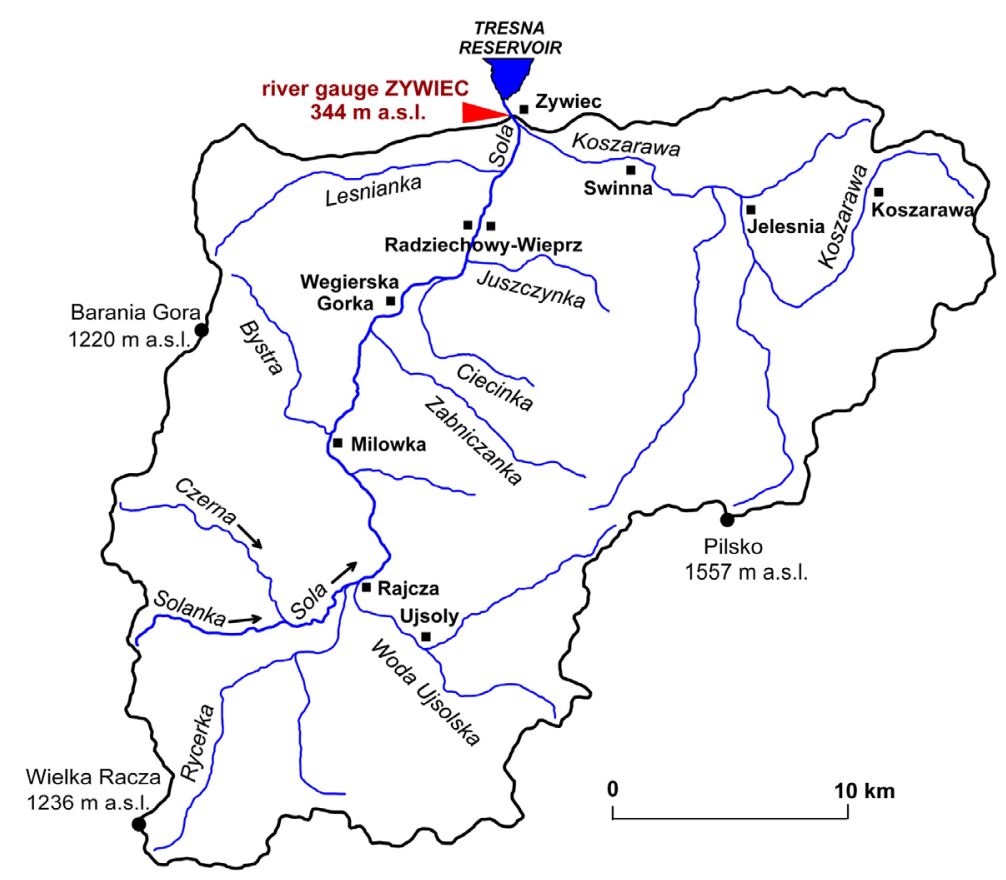

Figure 2. Upper Sola river catchment limited by the water-gauge ZYWIEC with the municipalities location

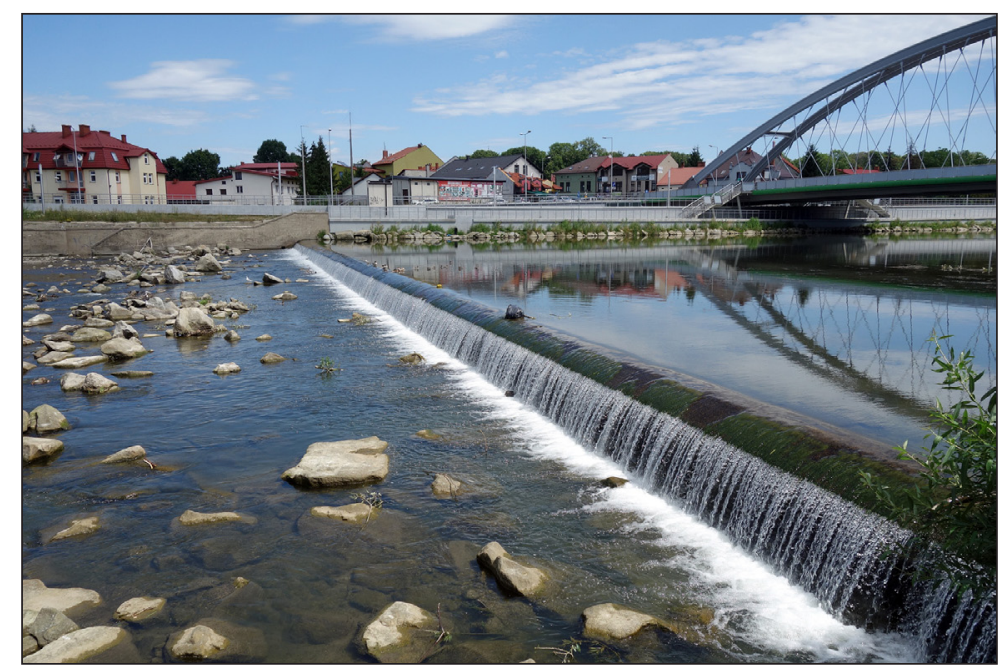

Figure 3. Water-gauge ZYWIEC cross-section on the Sola river (phot. by A. Jaguś)

Long-term flows are determined from annual flows. These are as follows:

- NNQ - the lowest minimum;

- $\mathrm{SNQ}$ - mean minimum;

- WNQ - the highest minimum;

- NSQ - the lowest mean;

- SSQ - mean long-term;

- WSQ - the highest mean;

- NWQ - the lowest maximum;

- $\mathrm{SWQ}$ - mean maximum;

- WWQ - the highest maximum.

- A monthly distribution of flows for the entire long-period was also presented. Mean monthly flows were presented (mean minimum, average mean, mean maximum).

In order to discuss the water resources protection, the analysis of land use was carried out for the drainage basin of the upper Sola. On the basis of topographic maps, the data obtained from the state administration units (municipalities) and CORINE Land Cover satellite images (2012) the land use structure was recognised, i.e. the arrangement and acreage of forest, farming, and other areas. 


\section{FLOWS OF THE SOLA RIVER}

As anticipated, the Sola flows featured a very broad range - from tenth parts of $\mathrm{m}^{3} / \mathrm{s}$ to a few hundred and more $\mathrm{m}^{3} / \mathrm{s}$. The lowest flow was $0.59 \mathrm{~m}^{3} / \mathrm{s}$ and occurred in December 2011, the next $-0.63 \mathrm{~m}^{3} / \mathrm{s}-$ in September 2015. Very low flows (less than $2 \mathrm{~m}^{3} / \mathrm{s}$ ) occurred also in the month considered the richest in precipitation, i.e. in July, e.g. $1.91 \mathrm{~m}^{3} / \mathrm{s}$ in $1962,1.59 \mathrm{~m}^{3} / \mathrm{s}$ in $1967,1.96 \mathrm{~m}^{3} / \mathrm{s}$ in 1987 , and $1.7 \mathrm{~m}^{3} / \mathrm{s}$ in 1994 . The highest flow was recorded in June 1958 - around $1250 \mathrm{~m}^{3} / \mathrm{s}$ then it was the flood with most disastrous effects in the Sola river valley. Very high flows, i.e. more than $900 \mathrm{~m}^{3} / \mathrm{s}$, occurred in July $1970\left(907 \mathrm{~m}^{3} / \mathrm{s}\right)$ and in July $1997\left(992 \mathrm{~m}^{3} / \mathrm{s}\right)$. Particularly large amounts of water were recorded longer-term in the Sola river bed in 2010 - in as many as three months of that year the maximum flow exceeded
$700 \mathrm{~m}^{3} / \mathrm{s}\left(729-746 \mathrm{~m}^{3} / \mathrm{s}\right)$. The variability of flows is best illustrated by the presentation of characteristic annual flows (Figure 4). The minimum flows (NQ) ranged from 0.59 to $3.04 \mathrm{~m}^{3} / \mathrm{s}$, mean (SQ) from 9.08 to $27.87 \mathrm{~m}^{3} / \mathrm{s}$, and the maximum ones (WQ) from 92.6 to $1250 \mathrm{~m}^{3} / \mathrm{s}$.

The minimum flows (NQ) reached $3 \mathrm{~m}^{3} / \mathrm{s}$, while the maximum ones (WQ) were at least $90 \mathrm{~m}^{3} / \mathrm{s}$. This contributes to high annual amplitudes - an average annual amplitude was as high as $353.6 \mathrm{~m}^{3} / \mathrm{s}$. The minimum and mean annual flows showed a weak upward trend (Figure 4), which can indicate the diminishing retention capacity of the drainage basin area. Instead, the annual maximum flows featured a slight downward trend (Figure 4). However, it is necessary to emphasise that all those trends were not statistically significant.

a)

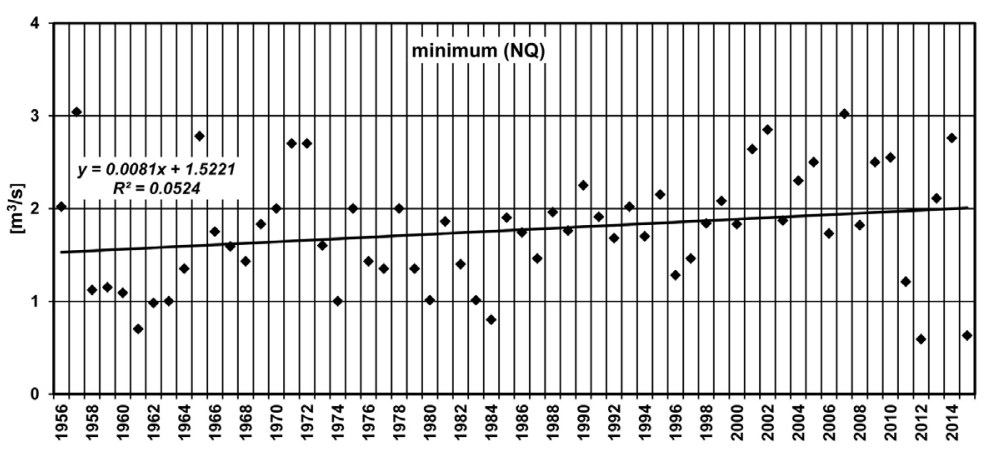

b)

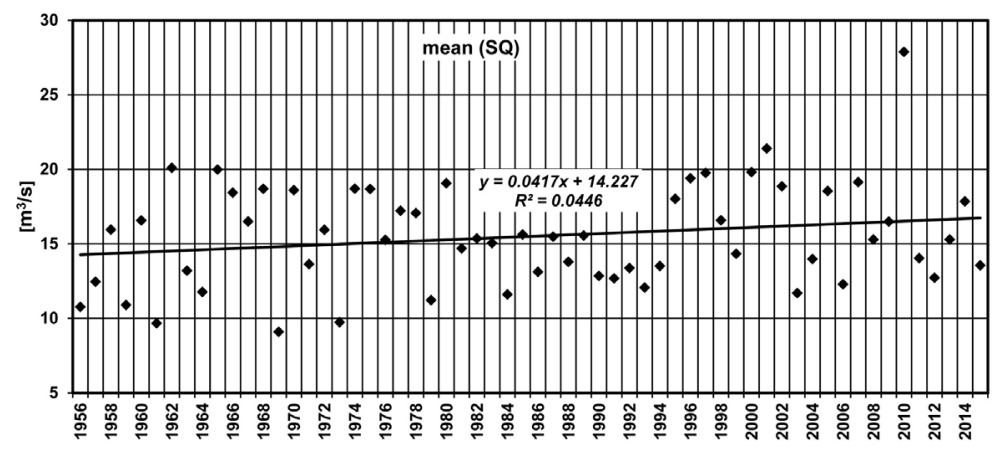

c)

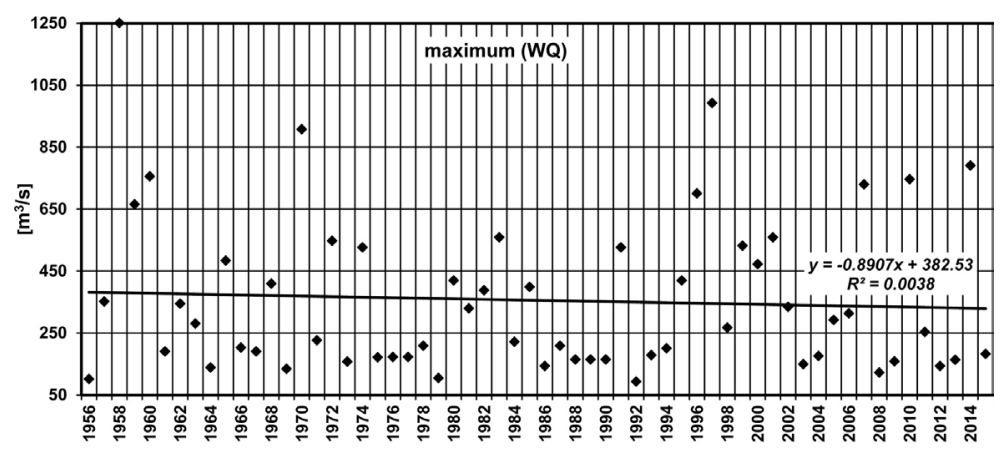

Figure 4. Annual characteristic flows of the Sola river (water-gauge ZYWIEC) 
A clear double growth within a year is visible in a monthly distribution of flows from the whole long period (Figure 5). The first rise occurs in spring (March-April) and is undoubtedly related to snow melting. It comprises both the minimum as well as mean and maximum flows. This results from slow melting of the snow cover, initially in the lower, then in the upper parts of the mountains. The second rise is related to summer rains (June-July) and applies practically only to maximum flows. The surface runoff occurs fast during the precipitation and does not last long after their end, which is generally visible in the area. The short-term passage of freshet waves is the effect. October is the month, during which the catchment area reaches the state of drainage - flows are the lowest (Figure 5). November rains start supplementing the water resources. Water accumulation in the form of a snow cover lasts from December to February. Obviously, in individual years there are deviations from the above-mentioned rules.

During the entire long period, October 1961 was the month of especially low amount of water in the Sola river. In that month, the flow did not exceed $2.01 \mathrm{~m}^{3} / \mathrm{s}$. Instead, during the whole April 2006 the river channel was heavily filled the flow did not go below $24.8 \mathrm{~m}^{3} / \mathrm{s}$. That was the effect of the mentioned slow melting of snow under mountain conditions.

Characteristic long-term flows (from hydrological years 1956-2015) for the ZYWIEC watergauge cross-section were as follows:

- $\mathrm{NNQ}-0.59 \mathrm{~m}^{3} / \mathrm{s}$;

- $\mathrm{SNQ}-1.769 \mathrm{~m}^{3} / \mathrm{s}$;

- WNQ - $3.04 \mathrm{~m}^{3} / \mathrm{s}$;

- $\mathrm{NSQ}-9.08 \mathrm{~m}^{3} / \mathrm{s}$

- $\mathrm{SSQ}-15.5 \mathrm{~m}^{3} / \mathrm{s}$

- WSQ - $27.87 \mathrm{~m}^{3} / \mathrm{s}$;

- NWQ - $93 \mathrm{~m}^{3} / \mathrm{s}$;

- $\mathrm{SWQ}-355.367 \mathrm{~m}^{3} / \mathrm{s}$;

- WWQ - $1250 \mathrm{~m}^{3} / \mathrm{s}$.

Specific outflow (from $1 \mathrm{~km}^{2}$ of area) from the drainage basin limited by the water-gauge, calculated based on SSQ is $19.8 \mathrm{dm}^{3} /\left(\mathrm{s} \cdot \mathrm{km}^{2}\right)$. Therefore, the drainage basin of the upper Sola should be classified among the areas where a significant part of Poland's water resources originates. The specific outflow in Polish upland areas is only a few $\mathrm{dm}^{3} /\left(\mathrm{s} \cdot \mathrm{km}^{2}\right)$, and in the lowland areas it does not exceed $2 \mathrm{dm}^{3} /\left(\mathrm{s} \cdot \mathrm{km}^{2}\right)(\mathrm{Fal}$ and Bogdanowicz 2002). As a result of high specific outflow, the Polish Carpathians, covering 6.3\% of Poland's area, supply $13 \%$ of national water resources (Starkel 1990).

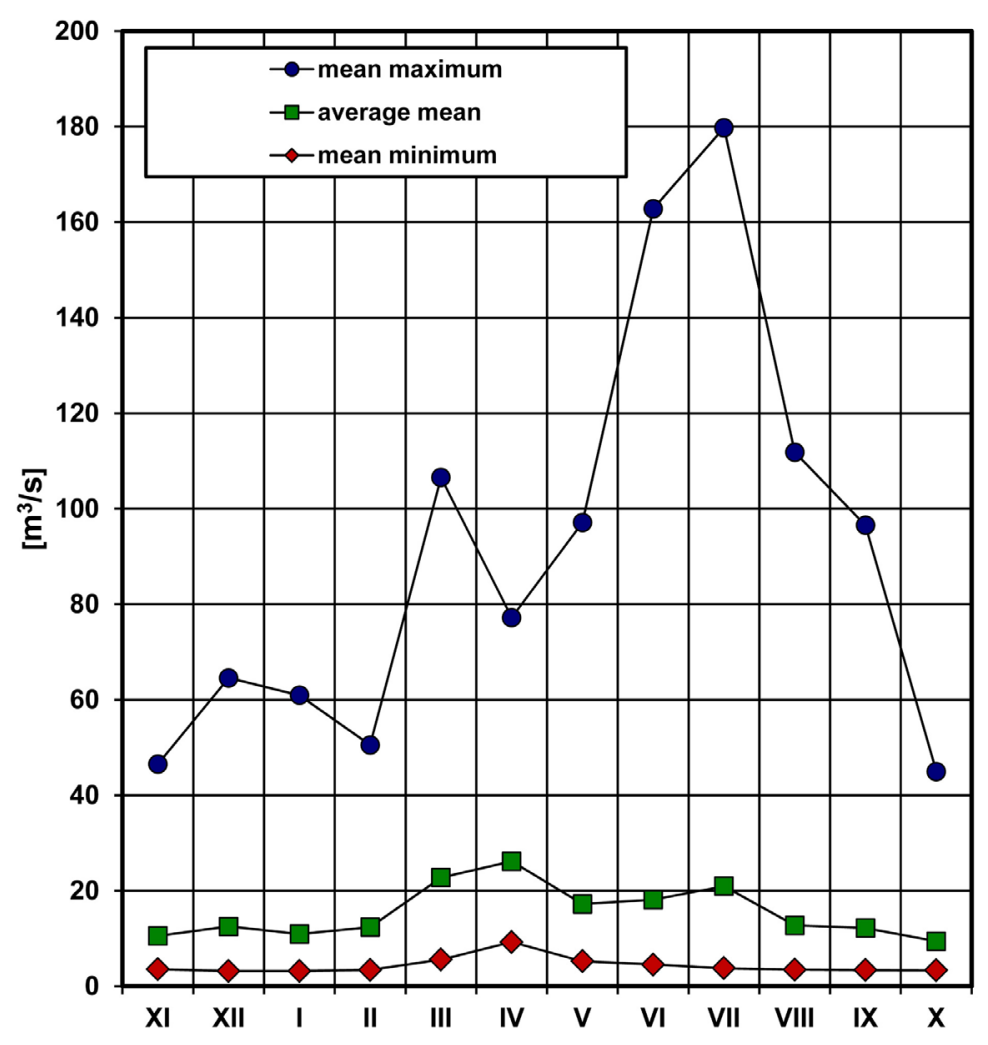

Figure 5. Monthly flows of the Sola river (water-gauge ZYWIEC) in the hydrological period 1956-2015 
The presented values of the Sola flows, in particular the values of maximum flows, show a too fast surface runoff of rain waters. Albeit the height of freshet wave of the upper Sola is reduced by the cascade reservoirs, it is not always to a safe level (Jagus 2018). The problem of sudden freshets applies to many rivers in the Polish Carpathians (Czaja et al. 2014), especially those which were not equipped with storage reservoirs. In the upper Sola drainage basin, due to the valley development, the construction of large dams is not possible; hence, the actions leading to the flows stabilisation are necessary.

\section{WATER RESOURCES PROTECTION}

The Actions stabilising the mountain rivers flows under the conditions of missing possibility to create dam reservoirs, must concentrate on the improved retention of the drainage basin area. A number of retention types may be distinguished (Mioduszewski 1999):

- landscape retention;

- soil retention;

- snow, including glacier, retention;

- underground water retention;

- surface waters retention.

Each type of retention can be shaped by people to a large extent. The overriding goal is to retain water on the ground surface and in the ground for a longer time in periods of its excess. Because of that the surface runoff may be reduced and the infiltration deep into the ground increased.

\section{LANDSCAPE RETENTION}

The retention capacity of mountain drainage basins depends to a large extent on the arrangement of basic land use forms, i.e. arable land, grassland, forests and paved areas (e.g. development, roads). This arrangement should be well adapted primarily to the elevation above sea level and to the ground slope. In the Carpathians, the climate changes with increasing elevation, and the slope gradients are usually increasing as well. In general, the watershed zones and steep slopes should be forested, and the riverside land developed as meadows. Arable and pasture farming may be carried out between forests and meadows, keeping in mind the minimisation of the number of roads, which will become water runoff lines during rainfalls. On the basis of long-term environmental studies in the Polish Carpathians summarised by Kurek (1990) the land use structure should be formed according to the following principles (Table 1):

in the areas below $500 \mathrm{~m}$ a.s.l., the arable land can cover $30-40 \%$ of the total area, grasslands $20-30 \%$, and forests approx. $30 \%$ (the other areas up to $10 \%$ );

1. in the areas between 500 and $700 \mathrm{~m}$ a.s.l. the share of arable land should not exceed $15-20 \%$, grasslands should cover not less than 20-30, and forests $50-55 \%$;

2. in the areas from 700 to $1000 \mathrm{~m}$ a.s.l. arable land should be entirely given up, $15-20 \%$ of the area designed for permanent grasslands and the rest should be covered by forests;

3. in the areas above $1000 \mathrm{~m}$ a.s.l. the permanent grasslands existing there may be periodically grazed, unless there are indications to the contrary from the environmental protection.

The structure of land use in the area of upper Sola drainage basin differs from the presented optimum one (Table 1). In all zones inhabited by people (up to $1000 \mathrm{~m}$ a.s.1.) a too small share of woodland areas is visible. In addition, a large part of forests is degraded due to relatively poor health of spruce-stands (domination of Picea ab$i e s)$, which were introduced as anthropogenic planting in the 19th century - originally beech-fir forests existed there (Sikorska and Lasota 2006). Poor spruce-stands have been attacked for a few decades by pests (especially Ips typographus) and they wither, also being felled by winds. Therefore, the forests with a high share of Picea abies are thinned out and have poor capacity to retain water. In the current situation it is indispensable to increase the acreage of woodlands and to reconstruct the stands into beech-fir stands with admixtures of other trees (e.g. pine, oak, larch, and sycamore).

The afforestation must be well planned and must apply mainly to the land not useful for farming - watershed areas, steep slopes, areas with soil of poor water permeability. It is necessary to remember that woodland areas, if not degraded, are very important from the flood protection point of view (they minimise the surface runoff), but much less important in supplying the underground waters, because the interception and evapotranspiration of forests is higher than that of other green 
areas (Mioduszewski 1999). The total water outflow from a forested catchment area is smaller than the outflow observed from a drainage basin with a small woodland area. The model studies of the afforestation impact on the hydrological situation prove, among other things, that after the afforestation the flows decrease and the duration of low flows is extended (Querner et al. 1997).

Another problem of the areas up to $1000 \mathrm{~m}$ a.s.l. is too small acreage of grassland (meadows and pastures) and at the same time an excessive size of arable land (Table 1). The arable land is not only situated too high, but also frequently on strongly sloping valley hillsides (especially of the main valley). Thus, the area of the arable land should be decreased, transforming it best to the meadow-pasture areas. Spontaneous plant successions - self-sodding and as a result self-afforestation should be prevented, because then the undesired species develop, like the problematic Picea abies and Juniperus communis, Betula pendula, Alnus incana, and others (Jagus and Skrzypiec 2017).

Large parts of areas situated above $1000 \mathrm{~m}$ a.s.l. are wasteland (Table 1). Apart from natural wasteland related to harsh climate conditions and to initial soil cover also large areas of windfall (forests felled by the wind) exist here, which should be afforested again. This zone has a potential for pasture use due to the existence of grassy land, which in the past was used in this way and now it is not used and degrading. Such areas should be made into extensive pastures or should be afforested.

In the studied drainage basin a high degree of its urbanisation draws attention, which in individual administration units (municipalities) ranges from a few up to $18 \%$ in the municipality of Wegierska Gorka. Unfortunately, the development is frequently dispersed, which results in a high number of access roads to houses. The water resources in the neighbourhood of development may be protected by construction of small storage facilities (ponds and small ponds) and by the rainwater accumulation and usage.

\section{Soil retention}

The soil retention should not be understood only in the context of water storage in the soil profile, but also in the sense of favourable conditions for the deep infiltration. In order to obtain proper soil retention in mountain areas, it is necessary to observe the rules of anti-erosion management.

In the Polish Carpathians, the greatest threat of water loss from the soil applies to the arable land and is related to the surface runoff (Lipski and Kostuch 2005). Therefore, the basic principle for this form of usage is the application of farming in strips going along the contour lines (never downhill). Under the conditions of a land slope, it is also necessary to remember that (Kurek 1990): 1 . arable use is relatively safe at the ground slope less than $6^{\circ}$;

Table 1. The structure of land use: optimal for the Polish Carpathians (Kurek 1990) and actual one in the upper Sola river catchment

\begin{tabular}{|c|c|c|c|}
\hline $\begin{array}{c}\text { Altitude } \\
\text { zone } \\
\text { [m a.s.l.] }\end{array}$ & The use form & $\begin{array}{l}\text { Polish Carpathians - optimal use } \\
\qquad[\%]\end{array}$ & $\begin{array}{c}\text { Upper Sola river } \\
\text { catchment - actual use [\%] }\end{array}$ \\
\hline \multirow{4}{*}{$<500$} & Forest & 30 & 18.5 \\
\hline & Grassland & $20-30$ & 16.5 \\
\hline & Arable land & $30-40$ & 43.0 \\
\hline & Urban/Road/Water/Rocks & 10 & 22.0 \\
\hline \multirow{4}{*}{$500-700$} & Forest & $50-55$ & 48.5 \\
\hline & Grassland & $20-30$ & 18.0 \\
\hline & Arable land & $15-20$ & 20.0 \\
\hline & Urban/Road/Water/Rocks & 5 & 13.5 \\
\hline \multirow{4}{*}{$700-1000$} & Forest & $80-85$ & 70.0 \\
\hline & Grassland & $15-20$ & 11.0 \\
\hline & Arable land & 0 & 7.5 \\
\hline & Urban/Road/Water/Rocks & Only natural wasteland & 11.5 \\
\hline \multirow{4}{*}{$>1000$} & Forest & Natural & 48.5 \\
\hline & Grassland & Only pastures & 31.0 \\
\hline & Arable land & 0 & 0.0 \\
\hline & Urban/Road/Water/Rocks & Only natural wasteland & 20.5 \\
\hline
\end{tabular}


2. in the area with slopes of $6-12^{\circ}$ arable farming is possible, but the application of anti-erosion crop rotation is needed;

3. arable land with slope of $12-20^{\circ}$ should be transformed into terraces;

4. arable land with slope exceeding $20^{\circ}$ should be transformed into permanent grassland or into forest.

The afore-mentioned anti-erosion crop rotation in the discussed area can consists of the following crops: mangold, oat with companion crop of clover, clover, winter triticale (Klima 1997). However, the meadow usage is the most favourable form of sloping land usage in terms of water resources protection. The farming on manure fertilised meadows formed from grass-clover mixtures minimises the surface runoff and ensures deep infiltration (Slupik 1973). At the same time, such meadows are the cheapest source of fodder for cattle and sheep breeding (Twardy et al. 2001).

The greatest problem of the farming land in the upper Sola drainage basin is the layout of plots (plough-land). Frequently they run in strips in accordance with slope gradients. This results from the land division through generations. The plots are narrow; therefore, farming is carried out in rows top down. This is favourable to the rainwater runoff. Thus, the necessary action consists in integrating in the plots and directing them along contour lines, i.e. perpendicularly to the gradient. It is also important to form small embankments planted with grass or with trees (e.g. Sorbus aucuparia) passing along contour lines between plots. They constitute a barrier to the running off water. The last barrier should consist of the strips of trees or bushes at least a few metres wide, passing along channels of rivers and streams.

\section{SNOW RETENTION}

Snow retention is a periodical retention of some amounts of water in the form of a snow cover (glaciers do not exist in the Polish Carpathians). Its melting starts in the early spring period. It proceeds at various intensities, depending mainly on the air temperature and sun exposure. It is desired that the snow melts slowly, which allows infiltration of a part of water deep into the ground. Under mountainous conditions, significant slowdown of snow melting results from the air temperature decrease with increasing elevation above sea level. In turn, the solar radiation intensity is lowest on the shaded slopes (in the Polish Carpathians these are the northern slopes) and inside forests. In the upper Sola drainage basin, snow maintains longest in forests, in particular those growing on northern mountain slopes. In the early spring period, the forests are most important for the supplementation of underground water resources (Mioduszewski 1999). Once again it is worth suggesting the appropriate afforestation of the catchment area, comprising mainly the land which is useless for farming.

\section{UNDERGROUND WATER RETENTION}

Underground water resources are a very important parameter of the environment affecting the river flows. This results from the fact that the underground water is the only source of river supply in periods without precipitation. It is enough to mention that the increase in the underground water retention, manifesting itself in its level raising in the ground, also results in increased low flows in rivers (Mioduszewski 1999).

The previously mentioned actions limiting the surface runoff and supporting water infiltration into the ground are favourable to the underground water retention. However, this retention depends on the geological structure, and more precisely - on the hydrogeological parameters of rock strata forming a specific area. The bedrock of the upper Sola drainage basin consists of Cretaceous and Palaeogene formations, comprised by so-called Carpathians flysh. These are layers of sandstone, shale, and marl, from tectonic point of view forming the Magura nappe (Malata 2008). Unfortunately, these strata are poorly water-bearing (Oszczypko et al. 1981). Underground water intakes (wells) are very rare in this area and are used to supply water to individual houses or to a few neighbouring houses. In such situation the care of the highest possible supply of underground waters is necessary.

\section{SURFACE WATERS RETENTION}

The surface waters retention is the volume of water in channels of water courses, in ditches, canals, and in all water reservoirs. To a large extent, this volume may be increased by people, e.g. via: - construction of various type weirs and contractions in water courses, to achieve the water level raising; 
- construction of small water reservoirs (ponds and small ponds);

- blocking the outflow from former ditches or drainage ditches;

- modification of riverbed courses extending the route of water flow (e.g. serpentine water courses).

It is necessary to emphasise that the outflow slowdown in water courses is favourable only in the non-urbanised areas. In the developed areas, a fast water outflow is required, because the water excess can threaten the infrastructure if water overflows the channel.

In the upper Sola drainage basin, there are great possibilities to increase the surface waters retention, except for riverside areas, where compact development areas are concentrated. The longer the distance from water courses, the more dispersed is the development. It may also disappear completely. There, it is possible to create various small retention facilities, like in the forest areas. Small retention facilities in the Polish Carpathians are encountered very seldom - these are actually only small ponds inside forest, made in the state owned forests. Increasingly often it is possible to encounter stream regulations that slow down the water flow rate (steps with waterfalls); however, they were not made for the retention purposes, but to reduce the movement of river debris.

\section{CONCLUSIONS}

The Sola river in its upper course is a typical mountain river with high dynamics of hydrological phenomena. Its drainage basin, like of other rivers in the Polish Carpathians, is a waterbearing area. The specific outflow of water from this drainage basin was determined on average as $19.8 \mathrm{dm}^{3} /\left(\mathrm{s} \cdot \mathrm{km}^{2}\right)$.

The flows of the upper Sola feature a broad range - in the ZYWIEC water-gauge profile in the hydrological long-period 1956-2015 they varied from 0.59 to $1250 \mathrm{~m}^{3} / \mathrm{s}$. A mean long-term flow was $15.5 \mathrm{~m}^{3} / \mathrm{s}$. The unevenness of flows (from short-term freshets to very low flows) results from both natural (high land gradient, poor waterbearing capacity of the bedrock) and anthropogenic factors (e.g. degradation of forest ecosystems, large number of roads, heavy urbanisation of riverside areas).
The monthly distribution of the Sola river flows during a year shows a rain-snow-underground regime of the river. Precipitation is the basic source of water and shapes mainly the zone of maximum flows. Snow thaw results in increased flows in all zones in the spring time. The flows diminish under the conditions of supply with only underground waters.

The widely observed surface runoff is the most unfavourable hydrological phenomenon. In order to minimise it the following are needed, in particular: reconstruction of the land use structure with the forest cover renovation, application of anti-erosion practice in farming, limitation of further development, and reduction of excessive number of roads, as well as increased surface waters retention.

\section{REFERENCES}

1. Baran-Gurgul K., Bodziony M., Kolodziejczyk K. 2018. Variability of the runoff coefficient for selected catchments in the Upper Vistula river catchment. Acta Scientiarum Polonorum Formatio Circumiectus, 17(3), 13-22.

2. Byczkowski A. 1999. Hydrology. Vol. I. Published by SGGW, Warszawa (in Polish).

3. Czaja S.W., Machowski R., Rzetala M. 2014. Floods in the upper part of Vistula and Odra river basins in the 19th and 20th centuries. Chemistry-DidacticsEcology-Metrology, 19(1-2), 127-134.

4. Dynowska I. 1991. Water cycle. In: Starkel L. (Ed.) Geography of Poland - natural environment. Published by PWN, Warszawa, 355-387 (in Polish).

5. Fal B., Bogdanowicz E. 2002. Surface waters resources of Poland. Wiadomosci Instytutu Meteorologii i Gospodarki Wodnej, 25(2), 3-38 (in Polish).

6. Jagus A. 2018. Economic and social importance of dam reservoirs - a study of the Sola River cascade. Inzynieria Ekologiczna, 19(1), 25-35 (in Polish).

7. Jagus A., Skrzypiec M. 2017. The soil-spatial conditions of agricultural activity in the area of Beskid Mts. Acta Scientiarum Polonorum Formatio Circumiectus, 16(2), 97-106 (in Polish).

8. Klima K. 1997. A protective aspect of mountain crop rotation. Acta Academiae Agriculturae ac Technicae Olstenensis - Agricultura, 64, 261-266 (in Polish).

9. Kurek S. 1990. Land use in water protection. Materialy Seminaryjne IMUZ, 27, 83-94 (in Polish).

10. Kusmierski E. 1991. Water balance of the Sola catchment for the river gauge Rajcza (methodological remarks). In: Jankowski A.T. (Ed.) Przeobrazenia stosunkow wodnych na obszarach silnej antropopresji. 
Published by PTG, Sosnowiec, 108-130 (in Polish).

11. Lipski C., Kostuch R. 2005. Soil erosion processes in the Carpathian mountain regions. Infrastruktura $\mathrm{i}$ Ekologia Terenow Wiejskich, 3, 95-105 (in Polish).

12. Malata T. 2008. Development of Polish Flysch Carpathians revealed in outcrops and landscape. Przeglad Geologiczny, 56(8/1), 688-691.

13. Mathison C., Wiltshire A.J., Falloon P., Challinor A.J. 2015. South Asia river-flow projections and their implications for water resources. Hydrology and Earth System Sciences, 19(12), 4783-4810.

14. Mioduszewski W. 1999. Protection and shaping of water resources in the agricultural landscape. Published by IMUZ, Falenty (in Polish).

15. Oszczypko N., Chowaniec J., Koncewicz A. 1981. Water pressure tests of the Magura sandstones. Rocznik Polskiego Towarzystwa Geologicznego, 51(1/2), 273-302 (in Polish).

16. Querner E.P., Tallaksen L.M., Kasparek L., Van Lanen H.A.J. 1997. Impact of land use, dimate change and groundwater abstraction on stream flow droughts, using physically based-models. IAHS Publication, 246, 171-179.

17. Ryffel A.N., Rid W., Gret-Regamey A. 2014. Land use trade-offs for flood protection: A choice experiment with visualizations. Ecosystem Services, 10, 111-123.

18. Sikorska E., Lasota J. 2006. Sites of fir forests in the Beskidy Zachodnie Mountains. Sylwan, 4, 3-13 (in Polish).
19. Slupik J. 1973. Differentiation of the surface run-off on flysh mountain slopes. Published by IG PAN, Warszawa (in Polish).

20. Starkel L. 1990. Spatial differentation of the Carpathian environment and the needs changes in land utilization. Problemy Zagospodarowania Ziem Gorskich, 30, 11-29 (in Polish).

21. Stoffel M., Wyzga B., Marston R.A. 2016. Floods in mountain environments: A synthesis. Geomorphology, 272, 1-9.

22. Twardy S., Kuzniar A., Kopacz M. 2001. The characterization of agriculture in the Polish Carpathians. In: Twardy S. (Ed.) Trwala okrywa roslinna jako podstawa zrownowazonego rozwoju rolnictwa $\mathrm{w}$ zlewniach karpackich. Published by IMUZ, Falenty, 230-237 (in Polish).

23. Walega A., Mlynski D. 2017. Seasonality of median monthly discharge in selected Carpathian rivers of the Upper Vistula basin. Carpathian Journal of Earth and Environmental Sciences, 12, 617-628.

24. Wrzesinski D., Sobkowiak L., Detection of changes in flow regime of rivers in Poland. Journal of Hydrology and Hydromechanics, 66(1), 55-64.

25. Wurbs R.A., Kim T.J. River flows for alternative conditions of water resources development. Journal of Hydrologic Engineering, 16(2), 148-156.

26. Wyzga B., Kundzewicz Z., Konieczny R., Piniewski M., Zawiejska J., Radecki-Pawlik A. 2018. Comprehensive approach to the reduction of river flood risk: Case study of the Upper Vistula Basin. Science of the Total Environment, 631-632, 1251-1267. 